\title{
然 \\ A OPÇÃO DO LEGISLADOR BRASILEIRO PELO MODELO PROCESSUAL PSEUDOACUSATÓRIO E A VIGÊNCIA DO IN DUBIO PRO HELL
}

\section{THE OPTION OF THE BRAZILIAN LEGISLATOR FOR THE FALSE MODEL OF DEMOCRATIC PROCESS AND THE VALIDITY OF IN DUBIO PRO HELL}

\section{LA OPCIÓN DEL LEGISLADOR BRASILEÑO PARA EL FALSO MODELO DE PROCESO DEMOCRÁTICO Y EL PLAZO DEL IN DUBIO PRO HELL}

\author{
Francisco José Vilas Bôas Neto ${ }^{1}$
}

\begin{abstract}
Resumo: O presente trabalho tratará da previsão do artigo $3^{\circ}$-A do Código de Processo Penal brasileiro, que prevê a estrutura acusatória. Serão apresentados dispositivos legais, posições doutrinárias e jurisprudências que afirmam ser esse o sistema do processo brasileiro. A hipótese consiste na possibilidade de o processo penal brasileiro não ser puramente acusatório, uma vez que essa estrutura parece não coincidir com alguns dispositivos legais. Será demonstrado que o processo penal brasileiro aproxima-se do modelo pseudoacusatório.
\end{abstract}

Palavras-chave: Processo Penal; Sistema Acusatório; Democracia.

Abstract: This text will deal with the prediction of the Brazilian Criminal Procedure Code, which provides for the accusatory structure. The hypothesis is that the Brazilian criminal process may not be purely accusatory, since this structure does not seem to coincide with some legal provisions. As will be demonstrated, the Brazilian criminal process is approaching a false accusation.

Keywords: Criminal Procedure; Accusatory System; Democracy.

Resumen: Este texto abordará la disposición del Código de Procedimiento Penal de Brasil, que establece la estructura acusatoria. Se presentarán disposiciones legales, posturas doctrinales y jurisprudencia que afirman ser el sistema del proceso brasileño. La hipótesis es que el proceso penal brasileño puede no ser puramente acusatorio, ya que esta estructura no parece coincidir con algunas disposiciones legales. Se demostrará que el proceso penal brasileño se acerca al falso modelo acusatorio.

Palabras clave: Procedimiento penal; Sistema acusatorio; Democracia.

\section{INTRODUÇÃO}

In dubio pro hell?

O vocábulo latino in dubio pro reo é amplamente conhecido entre os operadores do direito, precisamente entre àqueles que atuam com o direito penal. O termo designa que em caso de dúvida, deverá ser aplicada a decisão mais favorável ao acusado. Já o termo in dubio pro hell, utilizado por Rosa

\footnotetext{
${ }^{1}$ Doutorando em Direito, na linha de pesquisa Intervenção Penal e Garantismo, pela Puc Minas; mestre em Filosofia pela FAJE/MG; pós-graduado em Direito pela UCAM/RJ; graduado em Direito pela Puc Minas; advogado Criminalista. E-mail: vilasboas.f@hotmail.com
} 
e por Khaled Jr. (2017) no livro que levou esse título², é um jogo semântico transcrito na substituição da palavra latina reo (acusado) pela palavra inglesa hell (inferno).

Com a sugestão dada pelo novo princípio do in dubio pro hell, estaria a possibilidade de que a dúvida nem sempre favoreceria ao acusado. Partindo dessa premissa, o presente trabalho visa a questionar se o legislador brasileiro realmente fez uma opção pelo processo penal acusatório, ao incluir no Código de Processo Penal o artigo $3^{\circ}-\mathrm{A}^{3}$ que expressamente aponta para essa direção.

Apesar do art. $3^{\circ}$-A, introduzido no ordenamento pela Lei 13.964 de 24 de dezembro de 2019, a legislação processual penal brasileira é de fato acusatória? A hipótese discutida no texto apontará que o sistema processual brasileiro seria pseudoacusatório, não preenchendo os requisitos de um sistema acusatório puro.

Sem obedecer a uma estrutura rígida, inicialmente serão descritos os modelos processuais comuns, para em seguida serem demonstrados os dispositivos legais que afastariam o modelo brasileiro do modelo acusatório puro.

\section{SISTEMAS PROCESSUAIS}

O sistema processual penal é aquele utilizado em determinado ordenamento jurídico para que o Estado possa exercer o potestas puniendi ${ }^{4}$ (poder de punir). Em síntese, o sistema processual delimita as regras de investigação, processamento e execução da lei, para que o infrator possa ser passível da intervenção penal. No texto A imoralidade como direito fundamental e a etiqueta do direito penal ${ }^{5}$ é apontado que o direito penal é a legitimação da violência praticada pelo Estado contra o indivíduo particular. O Estado efetivamente pratica uma violência contra o infrator ao submetê-lo à limitação de liberdade de locomoção e à segregação social.

A violência do Estado, no entanto, é impunível. Ela pertence ao exercício do potestas puniendi. Ao aplicar a pena, o Estado possui o poder de exercer violência sobre o infrator, sendo por essa razão que existe a necessidade de limitação desse poder. No Estado Republicano, como é o caso do Brasil, a limitação do poder de punir é descrita na lei. É a lei processual e o sistema processual adotado que estabelecem as regras para que o Estado possa aplicar a pena ao infrator. Tradicionalmente a literatura processual penal, como será visto adiante, aponta três modelos processuais, sendo o inquisitivo, o acusatório e o misto.

\footnotetext{
${ }^{2}$ ROSA, Alexandre de Morais; KHALED JR. Salah. In dubio pro hell. Profanando o sistema penal. Editora EMais, $3^{\mathrm{a}}$ edição. Florianópolis, 2017.

${ }^{3} \mathrm{CPP}$. Art. $3^{\circ}$-A. O processo penal terá estrutura acusatória, vedadas a iniciativa do juiz na fase de investigação e a substituição da atuação probatória do órgão de acusação. (Incluído pela Lei no 13.964 , de 2019)

${ }^{4} \mathrm{O}$ termo potestas puniendi (poder de punir) foi escolhido no lugar do termo jus puniendi (direito de punir), por entender o autor que a pena é a imposição de sofrimento como retribuição ao crime. Ninguém, nem mesmo o Estado, tem o direito de impor sofrimento à pessoa.

5 Texto desse autor publicado na Revista de Direito Penal, Processo Penal e Constituição em 2018. Disponível pelo link https://www.indexlaw.org/index.php/direitopenal/article/view/3946/pdf
} 


\title{
2.1 Sistema Inquisitivo
}

O termo inquisitivo, com origem etimológica na expressão latina inquisitīus, descreve um modelo processual tendo como pressuposto a inquirição ou indagação pela inquisição. Segundo Pacelli (2012) o termo demonstra um model processual no qual o juiz atua também na fase de investigação; o processo se inicia com a notitia criminis, seguindo a investigação, acusação e julgamento.

No mesmo sentido:

\begin{abstract}
Adotado pelo Direito canônico a partir do século XIII, o sistema inquisitorial posteriormente se propagou por toda a Europa, sendo empregado inclusive pelos tribunais civis até o século XVIII. Tem como característica principal o fato de as funções de acusar, defender e julgar encontrarem-se concentradas em uma única pessoa, que assume assim as vestes de um juiz acusador, chamado de juiz inquisidor. (BRASILEIRO DE LIMA, 2013, p. 03).
\end{abstract}

Ainda segundo Brasileiro de Lima (2013), um juiz com essa concentração de poderes ficaria psicologicamente atrelado ao resultado, carecendo de objetividade e imparcialidade. Távora e Alencar vão além, ao afirmar que:

O princípio inquisitivo é caracterizado pela inexistência de contraditório e de ampla defesa, com concentração das funções de acusar, defender e julgar em uma única figura (juiz). O procedimento é escrito e sigiloso, com o início da persecução, produção da prova e prolação da decisão pelo magistrado. (TÁVORA E ALENCAR, 2013, p. 40).

Aury Lopes Jr. (2007) reconhece que esse modelo de procedimento incide num erro psicológico ao crer que uma mesma pessoa possa exercer funções tão paradoxais como investigar, acusar, defender e julgar.

Távora e Alencar salientam ainda que no modelo inquisitivo:

O discurso de fundo é a efetividade da prestação jurisdicional, a celeridade e a necessidade de segurança, razão pela qual o réu, mero figurante, submete-se ao processo numa condição de absoluta sujeição, sendo em verdade mais um objeto da persecução do que sujeito de direitos. (TÁVORA E ALENCAR, 2013, p. 40).

O acusado, mero coadjuvante da persecução penal, teria papel secundário num procedimento que visaria apenas extrair-lhe a confissão ou culpa. Não haveria a necessidade de preservação das garantias como o contraditório e a ampla defesa.

Afirma Távora e Alencar (2013) que um procedimento na linha inquisitiva seria de inspiração fascista, próprio de um Estado autoritário. Essa autojustificação do poder do juiz não encontra respaldo numa democracia. Como descrito no texto A fundamentação das decisões e o exercício efetivo do contraditório $^{6}$, a democracia, entendida como soberania popular, exige que a resposta judicial seja dada a partir da construção participada das decisões, ou seja, a partir do princípio do contraditório.

\footnotetext{
${ }^{6}$ Texto desse autor, em coautoria, publicado na Revista Eletrônica do Programa de Pós-graduação da Câmara dos Deputados E-Legis, em 2019. Disponível pelo link http://e-legis.camara.leg.br/cefor/index.php/e-legis/article/view/527/691 
Cumpre ressaltar que no ordenamento jurídico brasileiro cabe à Polícia Judiciária (em regra) ${ }^{7}$ a função de investigar e ao Ministério Público as funções de persecução e acusação criminal. Ao juiz caberia somente a função de julgar. Será?

\subsection{Sistema Acusatório}

Ao contrário do sistema inquisitivo, o sistema acusatório não permite a possibilidade do julgador exercer as funções de investigação e acusação. Nesse sentido é a previsão do Código de Processo Penal (CPP) que no artigo $3^{\circ}$-A traz que o processo penal terá estrutura acusatória, vedadas a iniciativa do juiz na fase de investigação e a substituição da atuação probatória do órgão de acusação.

Inobstante o fato de o dispositivo legal supracitado ter entrado em vigor somente em 2020, a partir da promulgação da Lei 13.964 de 24 de dezembro de 2019, certo é que a literatura jurídica já reconhecia o sistema processual brasileiro como sendo acusatório.

Sobre a questão em comento:

Como se depreende, embora o Código de Processo Penal brasileiro seja inspirado preponderantemente em princípios inquisitivos - conquanto existam dispositivos inseridos pelas sucessivas reformas que prestigiam o sistema acusatório -, a sua leitura deve ser feita à luz da Constituição, pelo que seu modelo de processo deve se adequar ao constitucional acusatório. (TÁVORA E ALENCAR, 2013, p. 42).

No mesmo sentido:

O sistema acusatório pressupõe as seguintes garantias constitucionais: da tutela jurisdicional (art. $5^{\circ}, \mathrm{XXXV}$ ), do devido processo legal (art. $5^{\circ}$, LIV), da garantia do acesso à justiça (art. $5^{\circ}$, LXXIV), da garantia do juiz natural (art. $5^{\circ}$, XXXVII e LIII), do tratamento paritário das partes (art. $5^{\circ}$, caput e I), da ampla defesa (art. $5^{\circ}, \mathrm{LV}, \mathrm{LVI}$ e LXII), da publicidade dos atos processuais e motivação dos atos decisórios (art. 93, IX) e da presunção de inocência (art. $5^{\circ}$, LVII) (Criminologia, cit. P.31-8). É o sistema vigente entre nós. (CAPEZ, 2013, p. 85).

Verifica-se pelas citações acima, que mesmo antes da entrada em vigor do artigo $3^{\circ}$-A do CPP, o sistema acusatório já era reconhecido como vigente no Brasil. Como característica, o sistema acusatório prevê a separação entre as funções de investigar, acusar e julgar, vedando a concentração dessas atribuições em uma única pessoa ou órgão. (PACELLI, 2012, p. 10). Esse também é o entendimento jurisprudencial do Superior Tribunal de Justiça (STJ):

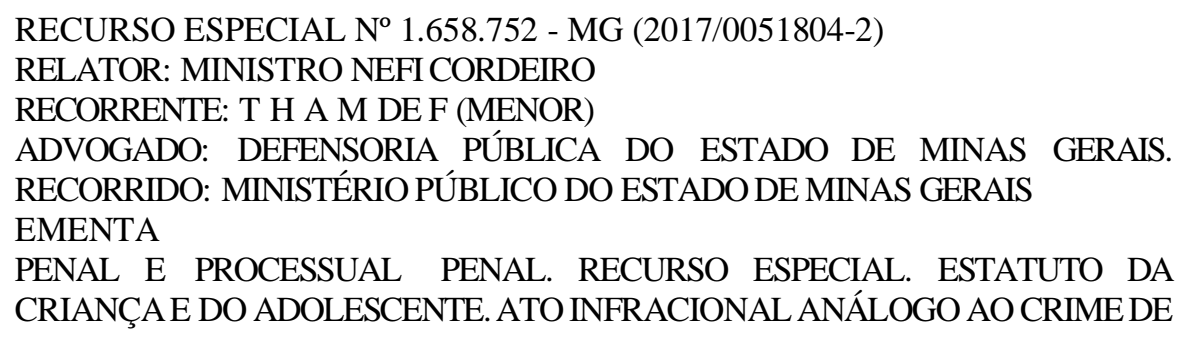

\footnotetext{
${ }^{7}$ Quando houver o interesse público, a lei admite a investigação pelo Ministério Público com a instauração dos inquéritos civis e administrativos.
} 
TRÁFICO DE DROGAS. LAUDO TOXICOLÓGICO DEFINITIVO JUNTADO APÓS A SENTENÇA. APELAÇÃO EXCLUSIVA DA DEFESA. TRIBUNAL A QUO SUSCITOU NULIDADE DE OFÍCIO. OFENSA AO SISTEMA ACUSATÓRIO. RECONHECIMENTO IMPLÍCITO DA AUSÊNCIA DE MATERIALIDADE DO ATO INFRACIONAL. RECURSOPROVIDO.

1. Constitui alicerce do processo penal brasileiro o sistema acusatório, no qual, emoposição à modalidade inquisitorial, impõe-se uma clara divisão de atribuições entre os sujeitos processuais responsáveis por acusação, defesa e julgamento na persecução criminal. (HC 347.748/AP, Rel. Ministro JOEL ILAN PACIORNIK, QUINTA TURMA, julgado em 27/09/2016, DJe 10/10/2016).

2. A posição do Colegiado de origem em suscitar e reconhecer preliminar de nulidade, esquivando-se da matéria trazida em apelação defensiva para julgá-la prejudicadae determinar seja proferida nova sentença, feriu o sistemaacusatório.

3. A Terceira Seção desta Corte Superior firmou entendimento de que, a despeito da necessidade do laudo toxicológico definitivo para aferir a materialidade do ato infracional, admite-se a sua comprovação outros meios de prova que possuam grau de certeza idêntico ao do laudo definitivo.Precedentes.

4. Recurso especial provido para cassar o acórdão recorrido e determinar o retorno dos autos ao Tribunal de origem para que prossiga no julgamento do recurso de apelação, aferindo a materialidade do ato infracional, consideradas as provas existentes ao tempo da prolação da sentença. (BRASIL, STJ, 2018).

Da mesma forma, no julgamento do habeas corpus número 404.228, o Ministro Jorge Mussi do STJ (BRASIL, 2018) aduziu que no Brasil prevalece o sistema acusatório, que "prima pela distribuição das funções de acusar, defender e julgar a órgãos distintos". Se no sistema inquisitivo estaria prevista a figura do juiz-acusador, o sistema acusatório autoriza somente que o juiz exerça a sua função na condição de órgão jurisdicional. A função do juiz estaria adstrita a analisar a acusação para absolver ou condenar o acusado.

Para Capez (2013), no processual acusatório é imprescindível o respeito ao contraditório e a ampla defesa. O juiz teria somente a função decisória, não participando da colheita de provas. Assim ele manteria a sua imparcialidade. Corroborando com o sobredito:

Pelo sistema acusatório, acolhido de forma explícita pela Constituição Federal de 1988 (CF, Art. 129, inciso I), que tornou privativa do Ministério Público a propositura da ação penal pública, a relação processual somente tem início mediante a provocação de pessoa encarregada de deduzir a pretensão punitiva (ne procedat judex ex officio) e, conquanto não retire do juiz o poder de gerenciar o processo mediante o exercício do poder de impulso processual, impede que o magistrado tome iniciativas que não se alinham com a equidistância que ele deve tomar quanto ao interesse das partes. Deve o magistrado, portanto, abster-se de promover atos de ofício na fase investigatória, atribuição esta que deve ficar a cargo das autoridades policiais e do Ministério Público. (BRASILEIRO DE LIMA, 2013, p. 05).

Como defendido no texto A fundamentação das decisões e o exercício efetivo do contraditório uma decisão fundamentada a partir do princípio constitucional do contraditório terá a sua legitimidade materializada na participação concreta dos demais sujeitos processuais.

\footnotetext{
8 Texto desse autor, em coautoria, publicado na Revista Eletrônica do Programa de Pós-graduação da Câmara dos Deputados E-Legis, em 2019. Disponível pelo link http://e-legis.camara.leg.br/cefor/index.php/e-legis/article/view/527/691
} 


\subsection{Sistema Misto}

O sistema processual misto, como sugere o nome, seria uma adaptação do sistema inquisitivo ao sistema acusatório. O procedimento apresentaria tanto uma fase inquisitiva, sem contraditório e ampla defesa, quanto uma fase acusatória, na qual as funções de investigar, acusar e julgar seriam delimitadas e separadas. Sobre a questão:

O sistema misto tem raízes na Revolução Francesa, conjunto de movimentos políticosociais cujos ideais se disseminaram pela Europa continental, e possui, como marco legal, o Code d'Instruction Criminelle francês de 1808. Caracteriza-se por uma instrução preliminar, secreta e escrita, a cargo do Juiz, com poderes inquisitivos, no intuito da colheita de provas, e por uma fase contraditória (judicial) em que se dá o julgamento, admitindo-se o exercício da ampla defesa e de todos os direitos dela decorrentes [...] assim temos: Investigação Preliminar, a cargo da polícia judiciária; instrução preparatória, patrocinada pelo juiz instrutor e julgamento [...] sobre o crivo do contraditório e ampla defesa. (TÁVORA E ALENCAR, 2013, p. 42).

A primeira fase (na qual o juiz atuaria como investigador-acusador) possuiria uma instrução preliminar, quando sem respeito ao contraditório e a ampla defesa, seriam produzidas as provas. $\mathrm{Na}$ segunda fase, após oportunizar o direito de defesa ao acusado, o juiz proferiria a sua decisão condenatória ou absolutória. Uma leitura desatenta do nosso ordenamento poderá sugerir que o sistema adotado no Brasil seja misto, em razão da existência na persecução criminal de uma fase inquisitiva (inquérito policial) e de uma fase acusatória (ação penal). Sobre o tema, Pacelli (2012, p. 13) preleciona que "alguns alegam que a existência do inquérito policial na fase pré processual, já seria por si só, indicativa de um sistema misto; outros, com mais propriedade, apontam determinados poderes atribuídos aos Juízes no Código de Processo Penal”.

A questão da dúvida sobre o sistema adotado é solucionada com argumento da definição de sistema processual, caracterizado "como o exame do processo, isto é, da atuação do Juiz no curso do processo". (PACELLI, 2012, p. 13).

A consideração do inquérito policial como parte integrante do processo é equivocada. Tal afirmação seria errônea porque o inquérito policial não integra a fase processual. Não há a atuação efetiva do Juiz ou do Ministério Público. Conforme a exigência do artigo 155 do Código de Processo Penal, sequer o juiz poderá condenar um acusado com base exclusivamente nos elementos de informação constantes do inquérito 9 .

Sobre o tema:

Com origem que remonta ao Direito Grego, o Sistema Acusatório é o sistema adotado no Brasil, de acordo com o modelo plasmado na Constituição Federal de 1988. Com efeito, ao estabelecer como função privativa do Ministério público a promoção da ação penal (art. 129, I, CF/88), a Carta Magna deixou nítida a preferência por esse modelo, que tem por características fundamentais: separação entre as funções de acusar, defender e julgar, conferida a personagens distintos. (TÁVORA E ALENCAR, 2013, p. 41).

\footnotetext{
${ }^{9} \mathrm{CPP}$. Art. 155. O juiz formará sua convicção pela livre apreciação da prova produzida em contraditório judicial, não podendo fundamentar sua decisão exclusivamente nos elementos informativos colhidos na investigação, ressalvadas as provas cautelares, não repetíveis e antecipadas.
} 
No mesmo sentido:

Todavia, com o advento da Constituição Federal, que prevê de maneira expressa a separação das funções de acusar, defender e julgar, estando assegurado o contraditório e a ampla defesa, além do princípio da presunção e da não culpabilidade, estamos diante de um sistema acusatório. (BRASILEIRO DE LIMA, 2013, p. 5).

Pelos fundamentos elencados, mesmo possuindo uma fase preliminar inquisitiva, é possível afirmar que o sistema processual adotado no Brasil não é misto e tampouco inquisitivo. Por outro lado, é possível afirmar que o sistema processual brasileiro é puramente acusatório?

\section{O MODELO PROCESSUAL PSEUDOACUSATÓRIO E A VIGÊNCIA DO IN DUBIO PRO}

\section{HELL}

Inicialmente é preciso salientar que o sistema acusatório é o mais adequado para um Estado Democrático de Direito. Isso porque a Constituição da República, segundo o artigo $5^{\circ} \mathrm{LV}$ prevê que "aos litigantes, em processo judicial ou administrativo, e aos acusados em geral são assegurados o contraditório e a ampla defesa, com os meios de recurso a ela inerentes".

Em outras palavras: o contraditório é o exercício dialético desenvolvido pelos sujeitos processuais, consistente na construção participada das decisões. É preciso entender, conforme mencionado acima, que o contraditório não pertence apenas às partes (autor - acusado), mas também ao juiz. Para o processo democrático, o contraditório que interessa não deriva do verbo contradizer e sim do verbo "construir". Afirmar que o processo é o procedimento submetido ao contraditório não é o mesmo que dizer que o processo é o procedimento submetido à sua contradição. O processo submetido à contradição é o processo submetido à sua negação. A negação do processo, por sua vez, é a negação da democracia. (VILAS BOAS NETO, 2019, p. 199).

Além do princípio do contraditório, o sistema acusatório prevê uma série de importantes princípios constitucionais que devem ser observados devido ao alcance e amplitude na proteção de direitos e garantias individuais. Como referência é possível citar o princípio da garantia da tutela jurisdicional descrito no artigo $5^{\circ}, \mathrm{XXXV}$, da CR/88 que prevê que $a$ "lei não excluirá da apreciação do Poder Judiciário lesão ou ameaça a direito".

Da mesma forma é possível citar o princípio do devido processo legal, subscrito no artigo $5^{\circ}$ LIV que traz a garantia de que "ninguém será privado da liberdade ou de seus bens sem o devido processo legal". O Texto Constitucional impõe que todos sejam iguais perante a lei, como prevê o artigo $5^{\circ}$ caput:

Todos são iguais perante a lei, sem distinção de qualquer natureza, garantindo-se aos brasileiros e aos estrangeiros residentes no país a inviolabilidade do direito à vida, à liberdade, à igualdade, à segurança e à propriedade, nos termos seguintes. I: homens e mulheres são iguais em direitos e obrigações, nos termos desta Constituição. (BRASIL, 2020).

Assim, a previsão já mencionada do artigo $3^{\circ}$-A do Código de Processo Penal, que afirma a estrutura acusatória para o sistema brasileiro, parece consagrar a natureza democrática do processo 
penal. Todavia, conforme já salientado, para que um processo seja propriamente democrático, respeitando-se o sistema acusatório, se faz necessária a separação das funções da investigação, acusação e julgamento.

Apesar da previsão expressa do sistema acusatório, certo é que existem outras previsões legais no próprio CPP que flexibilizam essa estrutura, trazendo dúvida quanto ao modelo adotado no Brasil. A primeira previsão legal que parece contrariar a estrutura acusatória é descrita no artigo $28-\mathrm{A}, \S 5^{\circ}$, do Código de Processo Penal. O caput do artigo introduziu na legislação brasileira a previsão do acordo de não persecução penal, facultando ao Ministério Público (órgão acusador) propor um acordo para o acusado, desde que a infração penal seja sem violência ou grave ameaça e que a pena mínima não exceda a quatro anos.

Ocorre que o parágrafo quinto do referido artigo autoriza ao juiz (que não é órgão acusador), a recusar a homologação do acordo de não persecução penal, quando entender que ele não foi realizado de forma adequada ${ }^{10}$. Verifica-se uma ingerência do juiz na atuação do Ministério Público, que enquanto órgão acusador, teria a liberalidade para pugnar pelo arquivamento ou oferecer a denúncia contra o acusado. Da mesma forma teria a liberalidade, observadas as condições legais, para oferecer o acordo de não persecução penal.

Mas como se observa o acordo necessita do aval de um magistrado. Outra norma que parece não corresponder ao sistema acusatório é a descrita no parágrafo único do artigo 212 do CPP.

Art. 212. As perguntas serão formuladas pelas partes diretamente à testemunha, não admitindo o juiz aquelas que puderem induzir a resposta, não tiverem relação com a causa ou importarem na repetição de outra já respondida.

Parágrafo único. Sobre os pontos não esclarecidos, o juiz poderá complementar a inquirição. (BRASIL, CPP, consulta em 03/05/2020).

Nota-se que a legislação autoriza que o juiz formule perguntas para as testemunhas quando entender que existam pontos não esclarecidos. Ora, as testemunhas são arroladas pelo promotor no momento de oferecimento da denúncia e pelo acusado quando oferece a sua resposta a acusação. Caberia às partes (promotor e acusado) inquirir as suas testemunhas sobre os pontos que entendam convenientes. Se houver alguma dúvida após a inquirição das testemunhas, ela não poderia ser esclarecida por perguntas formuladas pelo juiz.

O princípio do in dubio pro reo, garantia do acusado, afirma que a dúvida sempre deverá ser em seu benefício. Se após os questionamentos do promotor e da defesa persistirem dúvidas que o juiz pretende sanar com as suas próprias perguntas, ele o fará em desfavor do acusado. Se a dúvida favorece ao acusado, é possível presumir que a resolução dela poderá acarretar em seu prejuízo.

\footnotetext{
${ }^{10}$ CPP. Art. 28-A. Não sendo caso de arquivamento e tendo o investigado confessado formal e circunstancialmente a prática de infração penal sem violência ou grave ameaça e com pena mínima inferior a 4 (quatro) anos, o Ministério Público poderá propor acordo de não persecução penal, desde que necessário e suficiente para reprovação e prevenção do crime, mediante as seguintes condições ajustadas cumulativa e alternativamente:(...) $\S 5^{\circ}$. Se o juiz considerar inadequadas, insuficientes ou abusivas as condições dispostas no acordo de não persecução penal, devolverá os autos ao Ministério Público para que seja reformulada a proposta de acordo, com concordância do investigado e seu defensor.
} 
Pode ser argumentado que a resolução da dúvida seja favorável ao acusado. A questão é que ele não precisa disso, pois a dúvida já o favorece. O acusado não precisa da certeza para a sua defesa, pois a dúvida já o beneficiará.

É possível concluir que ao formular as suas próprias perguntas para sanar os pontos não esclarecidos, o juiz atuará como verdadeiro órgão de acusação. Há outra situação que causa maior estranhamento. Caso o juiz não consiga sanar as suas dúvidas com as perguntas formuladas às testemunhas arroladas pelo promotor e pela defesa, ele poderá arrolar as suas próprias testemunhas. Pelo menos essa é a previsão do artigo 209 do CPP que traz que o juiz, quando julgar necessário, poderá ouvir outras testemunhas, além das indicadas pelas partes. Por que motivos o juiz produziria uma prova senão para condenar?

O artigo 386 do Código de Processo Penal autoriza ao juiz absolver quando não existirem provas suficientes.

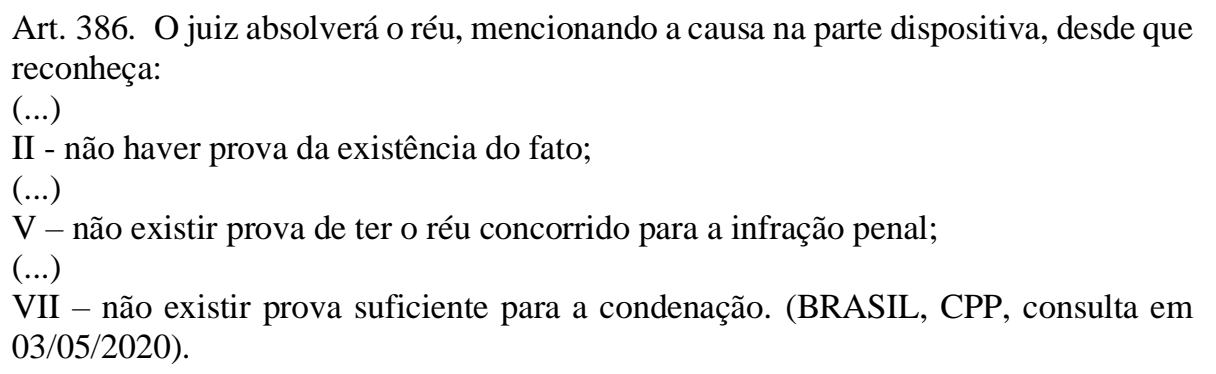

Se na falta de provas o juiz deve absolver conforme incisos II, V e VII do artigo 386 do CPP, ao insistir na produção delas, ao que parece, haverá um desejo de condenar. Assim como no caso anterior, a dúvida ou a falta de provas beneficia ao acusado. Então essa prova não é produzida a favor dele, mas em seu prejuízo.

Se pela falta de provas o magistrado deve absolver, ele não estaria substituindo o Ministério Público na função acusatória ao produzir as suas próprias provas? Parece, pelos exemplos acima, que há um afastamento do princípio do in dubio pro reo e uma aproximação ao novo (paradoxalmente antigo) princípio do in dubio pro hell.

A norma contida no artigo 234 do Código de Processo Penal, parecendo ter a mesma lógica da norma do artigo 209, também admite que o julgador possa produzir suas próprias provas, ao descrever que se o juiz tiver notícia da existência de documento relativo a ponto relevante, providenciará, independentemente de requerimento de qualquer das partes, a sua juntada aos autos.

Há ainda outra situação na legislação processual penal brasileira que, ao que indica, contraria o sistema acusatório puro. Como dito anteriormente, caberia ao promotor o oferecimento da ação penal pública, uma vez que ele é o investido da titularidade da ação penal. Em outras palavras, se o promotor não oferecer uma denúncia, não teríamos a possibilidade de um processo penal de ação pública. Todavia, apesar da ação pública ser de titularidade do Ministério Público, o juiz poderá proferir um decreto condenatório mesmo que não exista um pedido de condenação formulado pela acusação. 
Essa é a previsão do artigo 385 do CPP que descreve que "nos crimes de ação pública, o juiz poderá proferir sentença condenatória, ainda que o Ministério Público tenha opinado pela absolvição, bem como reconhecer agravantes, embora nenhuma tenha sido alegada”. O juiz está autorizado a condenar mesmo que o órgão de acusação tenha pedido a absolvição?

A lei autoriza e a jurisprudência do Superior Tribunal de Justiça acata a previsão legal.

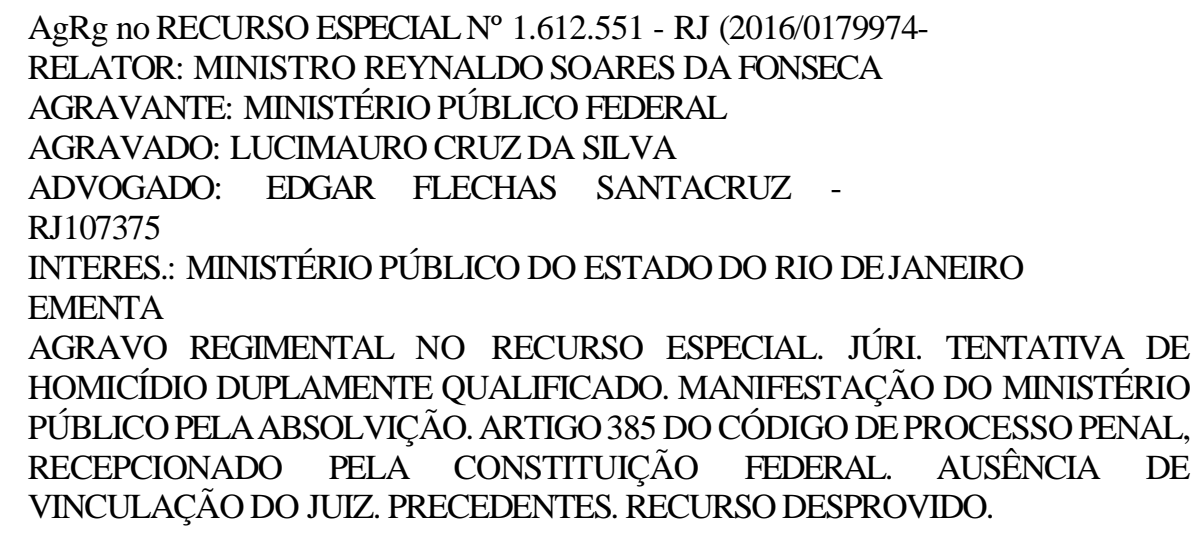

1. Nos termos do art. 385 do Código de Processo Penal, nos crimes de ação pública, o juiz poderá proferir sentença condenatória, ainda que o Ministério Público tenha opinado pela absolvição.

2. O artigo 385 do Código de Processo Penal foi recepcionado pela Constituição Federal. Precedentes desta Corte.

3. Agravo regimental não provido.

ACÓRDÃO. Vistos, relatados e discutidos os autos em que são partes as acima indicadas, acordam os Ministros da Quinta Turma do Superior Tribunal de Justiça, por unanimidade, negar provimento ao agravo regimental. Os Srs. Ministros Ribeiro Dantas, Joel Ilan Paciornik, Felix Fischer e Jorge Mussi votaram com o Sr. Ministro Relator.

Brasília (DF), 02 de fevereiro de 2017(Data do Julgamento)

Ministro REYNALDO SOARES DA FONSECA (BRASIL, STJ, 2016).

O Supremo Tribunal Federal (STF) adota a mesma linha do STJ:

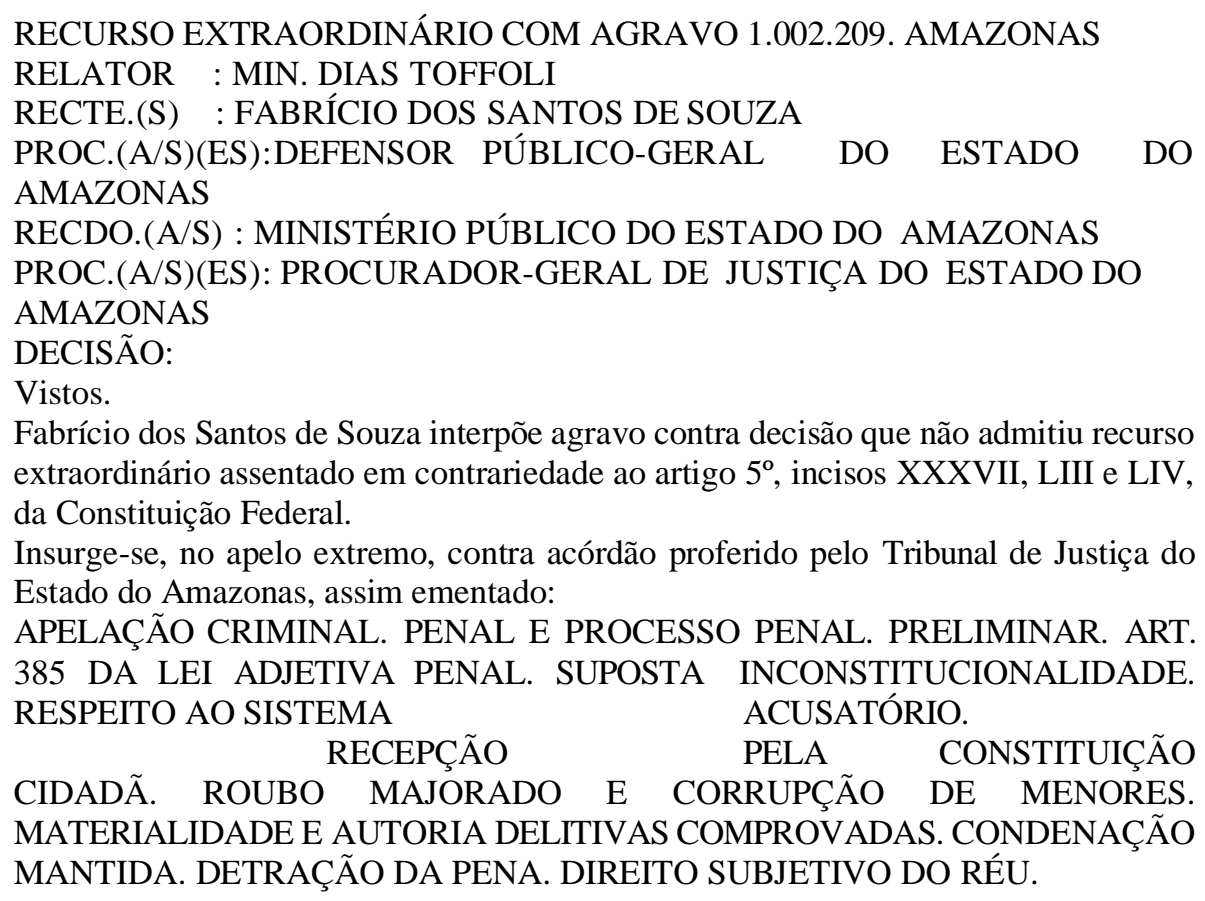


1. O art. 385 do CPP foi recepcionado pela Constituição Cidadã de 1988, por constituir vertente do próprio sistema acusatório, do princípio do livre convencimento motivado.

2. Sendo o conjunto probatório apto à comprovação da materialidade e autoria delitivas dos crimes de roubo majorado e corrupção de menores, não deve ser acolhido o requerimento de absolvição por insuficiência de lastro probatório.

3. Defere-se o requerimento de detração da pena, por constituir direito subjetivo do reú. Apelação criminal conhecida e parcialmente provida. (BRASIL, STF, 2016).

Como poderia um juiz em tese imparcial, dentro do sistema acusatório, condenar após o pedido de absolvição formulado pelo Ministério Público?

Como sustentado no texto O artigo 385 do Código De Processo Penal brasileiro e o sistema processual acusatório $(2017)^{11}$, o referido dispositivo legal deveria ser considerado como inconstitucional. Todavia, conforme as jurisprudências do STF e do STJ mencionadas acima, o entendimento jurisprudencial majoritário foi pela recepção do artigo 385 do CPP pela Constituição brasileira.

Apesar das decisões dos Tribunais Superiores, é possível encontrar jurisprudências em sentido contrário, como é o caso da decisão proferida pelo Tribunal de Justiça do Estado de Minas Gerais (TJMG).

Apelação Criminal 1.0702.09.565907-5/001

Des.(a) Alexandre Victor de Carvalho

Data da publicação da súmula 02/07/2012

APELAÇÃO - ROUBO MAJORADO - PEDIDO DE ABSOLVIÇÃO APRESENTADO PELO MINISTÉRIO PÚBLICO EM ALEGAÇÕES FINAIS VINCULAÇÃO DO JULGADOR - SISTEMA ACUSATÓRIO - ABSOLVIÇÃO DECRETADA.

I - Deve ser decretada a absolvição quando, em alegações finais do Ministério Público, houver pedido nesse sentido, pois, neste caso, haveria ausência de pretensão acusatória a ser eventualmente acolhida pelo julgador. II - O sistema acusatório sustenta-se no princípio dialético que rege um processo de sujeitos cujas funções são absolutamente distintas, a de julgamento, de acusação e a de defesa. O juiz, terceiro imparcial, é inerte diante da atuação acusatória, bem como se afasta da gestão das provas, que está cargo das partes. O desenvolvimento da jurisdição depende da atuação do acusador, que a invoca, e só se realiza validade diante da atuação do defensor. III - Afirma-se que, se o juiz condena mesmo diante do pedido de absolvição elaborado pelo Ministério Público em alegações finais está, seguramente, atuando sem necessária provocação, portanto, confundindo-se com a figura do acusador, e ainda, decidindo sem o cumprimento do contraditório. IV - A vinculação do julgador ao pedido de absolvição feito em alegações finais pelo Ministério Público é decorrência do sistema acusatório, preservando a separação entre as funções, enquanto que a possibilidade de condenação mesmo diante do espaço vazio deixado pelo acusador, caracteriza o julgador inquisidor, cujo convencimento não está limitado pelo contraditório, ao contrário, é decididamente parcial ao ponto de substituir o órgão acusador, fazendo subsistir uma pretensão abandonada pelo Ministério Público. (BRASIL, TJMG, 2012).

11 Texto desse autor publicado na Revista argentina Pensamiento Penal, em 2017. Disponível pelo link http://www.pensamientopenal.com.ar/doctrina/45344-o-artigo-385-do-codigo-processo-penal-brasileiro-e-o-sistemaprocessual-acusatorio 
A decisão do TJMG encontra coro na literatura jurídica:

O Ministério Público é o titular da pretensão acusatória, e sem o seu pleno exercício, não dá oportunidade de o Estado exercer o poder de punir. O poder punitivo estatal está condicionado à invocação feita pelo MP através do exercício da pretensão acusatória. Assim, o pedido de absolvição equivale ao não exercício desse poder, ou seja, o acusador está abrindo mão de proceder contra alguém. Como consequência, o juiz por não fundamentar sua decisão condenatória em provas ou argumentar sobre elas, não pode o juiz condenar sem que a acusação tenha sido feita. (BARRETO, acesso em 03 de maio de 2020)

No mesmo sentido:

O Sistema Acusatório caracteriza-se pela presença de partes distintas, contrapondo-se acusação de defesa em igualdade de posições, e a ambas se sobrepondo um Juiz, de maneira equidistante e imparcial. Aqui há uma separação das funções de acusar defender e Julgar (BRASILEIRO DE LIMA, 2013, p. 4).

Sem prejuízo das divergências jurisprudenciais ou mesmo literárias e sem adentrar na discussão acerca da constitucionalidade ou não do artigo 385 do CPP, certo é que pela decisão do Supremo Tribunal Federal ele vigora plenamente no ordenamento jurídico brasileiro. Inobstante a previsão legal do artigo $3^{\circ}$-A do CPP estabelecer a estrutura acusatória, ou seja, a estrutura democrática do processo com prevalência do princípio do in dubio pro reo, certo é que a legislação processual brasileira, em muitos casos, se afasta do sistema processual acusatório puro, admitindo o princípio in dubio pro hell da forma ensinada por Rosa e Khaled Jr. (2017).

É preciso salientar que apesar da lei autorizar que em alguns casos o juiz atue como se acusação fosse, o sistema processual brasileiro não pode ser tido como inquisitivo ou misto. O mais adequado é afirmar que se trata de um sistema acusatório impuro ou um sistema pseudoacusatório. O Ministro Reynaldo Soares da Fonseca, em 2017, reconheceu que o sistema adotado não seria o acusatório:

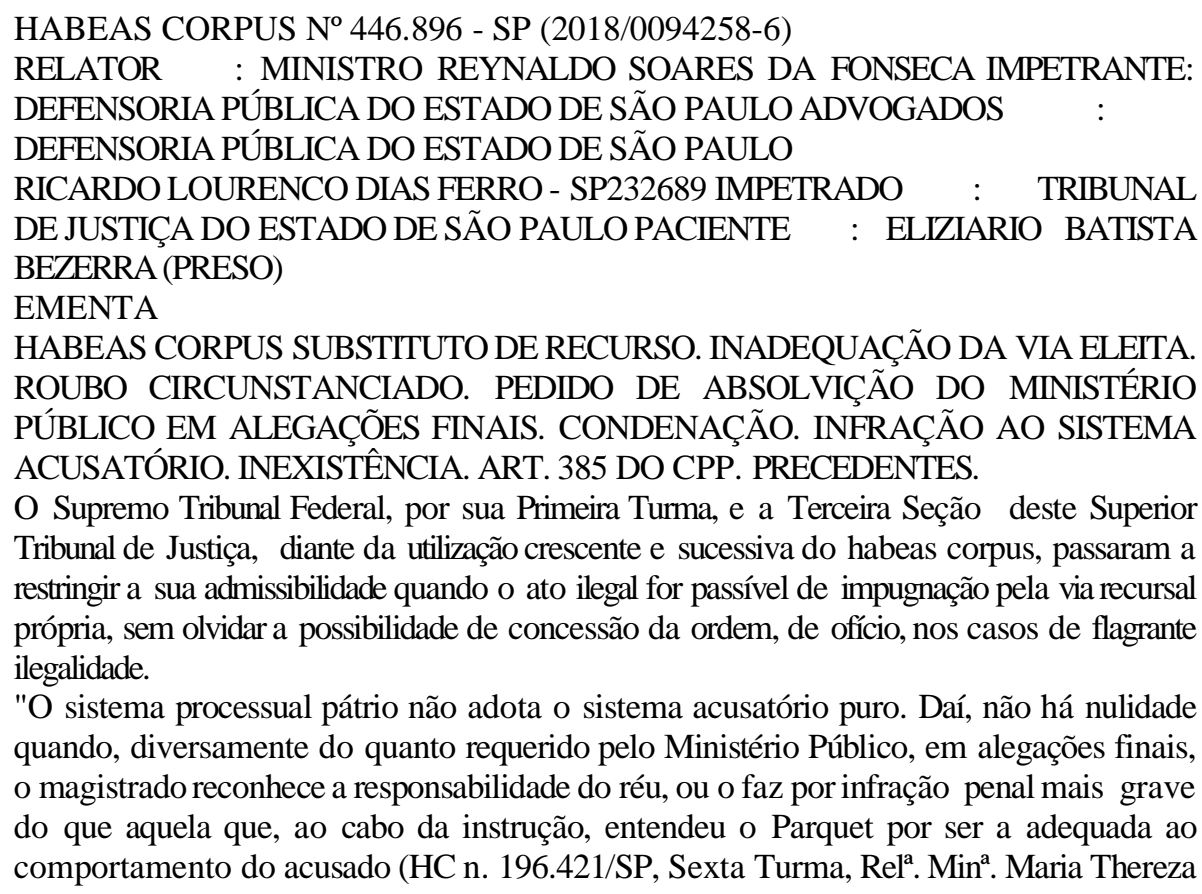


de Assis Moura, DJe de 26/2/2014). Assim, no caso, não há falar-se em nulidade da condenação do paciente pelo simples fato de o Parquet ter requerido sua absolvição.(HC 407.021/SC, Rel. Ministro FELIX FISCHER, Quinta Turma, julgado em 19/09/2017, DJe 25/09/2017)".

Habeas corpus não conhecido. (BRASIL, STJ, 2017).

$\mathrm{O}$ art. $3^{\circ}$-A do CPP aponta que a estrutura seja acusatória. A jurisprudência e a literatura jurídica coadunam com a previsão legal. Todavia, há previsões legais que autorizam o juiz a atuar em substituição a acusação. Esses dispositivos legais, mesmo questionáveis, são convalidados pela jurisprudência dominante. Para conciliar essas perspectivas aparentemente contrárias, é possível dizer que o sistema do Brasil seja pseudoacusatório. O legislador brasileiro parece ter adotado essa preferência ao trazer artigos como o 28-A, $\S 5^{\circ}$; -209; -212, parágrafo único; -234; e 385, todos do CPP.

\section{CONCLUSÃO}

Como exposto durante o trabalho, o artigo $3^{\circ}$-A do CPP brasileiro aponta que a estrutura processual adotada seria a acusatória. Diferentemente da estrutura inquisitiva que prevê a concentração das funções de investigação, acusação e julgamento em uma única pessoa ou órgão e diferente da estrutura mista que mesclaria a inquisitiva com a acusatória, a estrutura apontada no referido dispositivo legal pressupões a separação das funções de investigar, acusar e decidir.

Corroborando com a previsão legal está a literatura jurídica, conforme os apontamentos de Pacelli, Brasileiro de Lima, dentre outros. De uma forma geral a jurisprudência também aponta o sistema acusatório como sendo o adotado no Brasil, parecendo haver uma convergência de entendimentos entre o legislador, a academia, o operador do direito e o juiz.

Todavia, ao ser constatada a existência de previsões legais que autoriza ao juiz produzir provas, dirimir controvérsia e até mesmo condenar quando há um pedido absolutório do Ministério Público, surge dúvida quanto à pureza acusatória desse sistema. Tais dispositivos que parecem permitir ao juiz substituir a acusação se afastam da lógica processual do in dubio pro reo e se aproximam do descrito in dubio pro hell.

Considerando que o sistema brasileiro não é inquisitivo ou misto, vez que esses modelos sofrem objeções e rejeições pela literatura e pela jurisprudência, conclui-se, ao menos, que a estrutura do processo penal brasileiro é acusatória impura, ou como sugerido, pseudoacusatória.

\section{REFERÊNCIAS}

BRANDÃO, Claudio Bezerra. Tipicidade penal: dos elementos da dogmática ao giro conceitual do método entimemático. Editora Almedina, Coimbra, 2012.

BRANDÃO, Claudio Bezerra. Teoria Jurídica do Crime. Editora D’Plácido. Belo Horizonte, 2019.

BRASILEIRO DE LIMA, Renato. Curso de Processo Penal. Editora Impetus. Niterói, 2013.

BRASIL. Constituição da República Federativa do Brasil. Disponível em http://www.planalto.gov.br/ccivil_03/constituicao/constituicao.htm. Consulta realizada em 03/05/2020. 
BRASIL. Código de Processo Penal. Disponível em http://www.planalto.gov.br/ccivil_03/decretolei/del3689.htm. Consulta realizada em 03/05/2020.

BRASIL. Superior Tribunal de Justiça. Recurso especial $\mathrm{n}^{\circ}$ 1.658.752. Disponível em https://scon.stj.jus.br/SCON/decisoes/toc.jsp?processo=1.658.752\&b=DTXT\&thesaurus=JURIDICO\&p=true . Consulta realizada em 03/05/2020.

BRASIL. Superior Tribunal de Justiça. Habeas corpus $\mathrm{n}^{\circ}$ 404.228. Disponível em https://scon.stj.jus.br/SCON/decisoes/toc.jsp?processo=HC+404228\&b=DTXT\&thesaurus=JURIDICO\&p=true. Consulta realizada em 03/05/2020.

BRASIL. Superior Tribunal de Justiça. Recurso especial $\mathrm{n}^{\mathrm{o}}$ 1.612.551. Disponível em https://scon.stj.jus.br/SCON/decisoes/toc.jsp?processo=1.612.551\&b=DTXT\&thesaurus=JURIDICO\&p=true. Consulta realizada em 03/05/2020.

BRASIL. Superior Tribunal de Justiça. Habeas corpus $\mathrm{n}^{\circ}$ 446.896. Disponível em https://scon.sti.jus.br/SCON/decisoes/toc.jsp?processo=HC+446896\&b=DTXT\&thesaurus=JURIDICO\&p=true. Consulta realizada em 03/05/2020.

BRASIL. Supremo Tribunal Federal. Recurso extraordinário com agravo 1.002.209. Disponível em http://www.stf.jus.br/portal/jurisprudencia/listarJurisprudencia.asp?s1=\%28\%281002209\%2ENUME\%2E+OU+ 1002209\%2EDMS\%2E\%29\%29+NAO+S\%2EPRES\%2E\&base=baseMonocraticas\&url=http://tinyurl.com/y9n 48bva. Consulta realizada em 03/05/2020.

BRASIL. Tribunal de Justiça do Estado de Minas Gerais. Apelação criminal 1.0702.09.565907-5/001. Disponível:

https://www5.tjmg.jus.br/jurisprudencia/pesquisaNumeroCNJEspelhoAcordao.do;jsessionid=CE5E8334C19B0 B08B43F8E26E4F8A63E.juri_node2?numeroRegistro=1\&totalLinhas $=1 \&$ linhasPorPagina $=10$ \&numeroUnico $=$ 1.0702.09.565907-5\%2F001\&pesquisaNumeroCNJ=Pesquisar. Consulta realizada em 03/05/2020.

BRÊTAS, Ronaldo de Carvalho Dias. Processo constitucional e Estado Democrático de Direito. $4^{\text {a }}$ edição. Editora Del Rey. 2018.

CAPEZ, Fernando. Curso de Processo Penal. 20ª edição. Editora Saraiva. São Paulo, 2013.

COLEN, Guilherme Coelho; GONÇALVES, Antônio Fabrício de Matos; OLIVEIRA, Allan Helber de (organizadores). Direito processual atual. Editora Mandamentos. Belo Horizonte, 2002.

CRUZ, Clenderson. A ampla defesa no processualidade democrática. Belo Horizonte: Editora Lumen Juris, 2016.

FERRAJOLI, Luigi. Direito e razão: teoria do garantismo penal. $3^{\text {a }}$ edição. Editora Revista dos Tribunais, São Paulo, 2002.

GOMES FILHO, Antônio Magalhães. A motivação das decisões penais. $2^{a}$ edição. Editora Revista dos Tribunais. São Paulo, 2013.

LOPES JR, Aury. Direito processual penal e sua conformidade constitucional, volume I. Editora Lúmen Júris. Rio de Janeiro, 2007.

NASCIMENTO, Adilson de Oliveira. Dos pressupostos processuais penais. Editora Mandamentos, Belo Horizonte, 2008.

PACELLI, Eugênio. Curso de Processo Penal. 16a edição. São Paulo: Editora Atlas, 2012.

ROSA, Alexandre de Morais; KHALED JR. Salah. In dubio pro hell. Profanando o sistema penal. Editora EMais, $3^{a}$ edição. Florianópolis, 2017.

SILVA, José Afonso da. Curso de Direito Constitucional Positivo. 28ª edição. Editora Malheiros. São Paulo, 2002.

TÁVORA, Nestor; ALENCAR, Rosmar Rodrigues. Curso de Direito Processual Penal. $8^{\mathrm{a}}$ edição. Editora JusPodvm, Salvador, 2013.

TOURINHO FILHO, Fernando da Costa. Manual de Processo Penal. Editora Saraiva. São Paulo, 
2009.

VEIGAS, Carlos Athayde Valadares. Legitimidade democrática da jurisdição constitucional. Editora D'Plácido, Belo Horizonte, 2014.

VILAS BOAS NETO, Francisco José. O artigo 385 do código de processo penal brasileiro e o sistema processual acusatório. Revista Pensamiento Penal, s.v., s.n., 2017. Disponível em: http://www.pensamientopenal.com.ar/doctrina/45344-o-artigo-385-do-codigo-processo-penal-brasileiro-e-osistema-processual-acusatorio

VILAS BOAS NETO, Francisco José. A imoralidade como direito fundamental e a etiqueta do direito penal. Revista de Direito Penal, Processo Penal e Constituição, v.4, n.1, p. 106-124. 2018. Disponível em https://indexlaw.org/index.php/direitopenal/article/view/3946/pdf

VILAS BOAS NETO, Francisco José; MAIA, Tomiko Yoshimura Carvalho. A fundamentação das decisões e o exercício efetivo do contraditório. E-Legis, v.12, n. 30, p. 194-210, set./dez., p. 194-210, 2019. Disponível em http://e-legis.camara.leg.br/cefor/index.php/e-legis/article/view/527/691

Artigo recebido em: 2020-05-03

Artigo reapresentado em: 2020-06-24

Artigo aceito em: 2020-07-23 